\title{
KARAKTERISTIK SURFACE PARTIAL DISCHARGE DI SEKITAR ANTARMUKA PCB PADA PELAT-PELAT ELEKRODA PADA ISOLASI UDARA DAN MINYAK
}

\author{
Neris Peri Ardiansyah ${ }^{1}$, Resa Pramudita ${ }^{2}$ \\ Departemen Pendidikan Teknik Elektro ${ }^{1}$, Program Studi Teknik Elektro ${ }^{2}$ \\ Universitas Pendidikan Indonesia ${ }^{1}$, Universitas Widyatama ${ }^{2}$ \\ Jalan Setiabudhi No. 229 ${ }^{1}$, Jalan Cikutra no 204A², Kota Bandung \\ nerisperia@upi.edu $1{ }^{1}$ resa.pramudita@widyatama.ac.id ${ }^{2}$
}

\begin{abstract}
Abstrak
Penggunaan peralatan tegangan tinggi pada konverter elektronik daya atau modul daya memiliki pengaruh terhadap sistem isolasi peralatan yang digunakan. Efek yang dihasilkan adalah pelepasan sebagian atau partial discharge (PD), dimana hal tersebut depengaruhi oleh bentuk tegangan, yang mana fenomena PD ini adalah awal mula terjadinya kegagalan dalam suatu peralatan. Pada penelitian ini dilakukan Pengukuran PD dengan mengacu pada Standar IEC 60270 yang menggunakan metode elektrik sebagai pengukuran yang digunakan untuk pengujian PD pada bahan PCB dengan alat ukur yang digunakan adalah RC detektor dan High Frequency Current Transformer (HFCT). Pengukuran PD dilakukan dengan membuat model elektroda yang digunakan pada pengujian untuk membuat sumber PD. Elektroda yang digunakan adalah model elektroda Homogen pelat-pelat. Pengujian pada PCB dilakukan untuk mengetahui karakteristik surface discharge pada disekitar antarmuka pelat-pelat elektroda. Parameter yang digunakan dalam pengukuran yaitu Partial Discharge Inception Voltage (PDIV), Partial Discharge Extinction Voltage (PDEV), Bentuk Gelombang PD, dan Pola Phasa PD.
\end{abstract}

Kata kunci :

Surface Partial Discharge, elektroda pelat-pelat, Isolasi udara, Isolasi minyak, PCB.

\section{Abstract}

The use of high voltage equipment on the electronic power converter or power module has an influence on the equipment insulation system used. The resulting effect is a partial discharge (PD), where it is affected by the shape of the voltage, which is the phenomenon of $P D$ is the beginning of the failure in an equipment. In this study PD measurements were made with reference to the IEC 60270 Standard which uses the electrical method as a measurement used for PD testing on PCB materials with measuring instruments used are RC detectors and High Frequency Current Transformers (HFCT). PD measurements are made by making a model of the electrodes used in testing to create a PD source. The electrode used is the Homogeneous electrode model of the plates. Tests on the PCB are performed to determine the surface discharge characteristics around the interface of the electrode plates. The parameters used in the measurement are Partial Discharge Inception Voltage (PDIV), Partial Discharge Extinction Voltage (PDEV), PD Waveforms, and PD Phase Patterns.

Keywords :

Surface Partial Discharge, electrode plates, Air insulation, Oil insulation, $P C B$

\section{Pendahuluan}

Surface discharge merupakan salah satu fenomena peluahan permukaan di bahan isolasi padat, hasil berbagai tinjauan yang dilakukan terdapat beberapa kejadian surface discharge pada peralatan seperti busing, isolator, kabel, transformer dan Modul daya.

Salah satu permasalahan surface discharge diantaranya terjadi juga pada modul daya dimana penggunaan substrat seperti PCB yang terdapat pelat tembaga di kedua sisinya yang digunakan pada modul daya. 
Surface discharge dapat terjadi pada isolasi padat, udara dan minyak. Bebagai macam metode pengukuran dapat dilakukan, namun dalam pengujian kali ini menggunakan pengujian Partial Discharge sebagai salah satu metode pengujian yang dilakuan untuk mengetahui kondisi peralatan.

Metode deteksi yang digunakan dalam penelitian surface discharge menggunakan metode elektrik dan non elektrik. Pada metode elektrik digunakan sensor HFCT dan RC detektor.

Pada penelitian sebelumya telah diteliti terkait surface discharge (Fu et al., 2018; Ghaffarian, 2015; Mansour, Kojima, Hayakawa, Endo, \& Okubo, 2009) - Namun yang dilakukan dalam penelitian ini dilakukan objek pengujian pada PCB sebagai objek uji terjadinya surface discharge dengan menggunakaan jenis isolasi udara dan minyak, yang di ukur menggunakan sensor RC detektor dan HFCT pada elektroda pelat-pelat.

Penelitian ini dilakukan untuk mengetahui karakteristik Surface Discharge pada permukaan PCB di sekitar tepi lingkaran pelat - pelat elektroda di isolasi udara dan isolasi minyak dengan desain yang digunakan adalah elektroda pelat - pelat dengan objek uji Printed Circuit Board (PCB).

\section{KAJIAN LITERATUR}

Menurut standar IEC 60270, Partial Discharge (PD) adalah suatu fenomena peluahan listrik secara lokal yang menghubungkan secara parsial atau sebagian dari isolasi di antara konduktor dan yang terjadi baik di permukaan konduktor maupun di dalam konduktor (void) $(60270,2001)$.

Surface discharge atau pelepasan muatan permukaan adalah pelepasan muatan dari konduktor ke media gas atau cair dan terjadi pada permukaan material isolasi padat yang tidak tertutupi oleh konduktor.

Discharge dimulai di wilayah dengan medan listrik yang tinggi, tetapi dapat kemudian merambat ke daerah yang memiliki cukup tekanan untuk memulai pelepasan permukaan. Pelepasan permukaan terjadi karena kekuatan dielektrik antar muka isolasi dielektrik lebih kecil dari kekuatan dielektrik masingmasing. Pelepasan pemukaan dapat terjadi pada ujung kabel jika ada penilaian yang buruk untuk terminasi kabel tersebut. Hal ini juga dapat terjadi pada busing, atau pada permukaan garis-insulator. Seperti terlihat pada gambar 1 menunjukkan tempat-tempat dimana terjadi pelepasan permukaan selama proses desain peralatan bertegangan tinggi, menempatkan antarmuka isulasi dielektrik ke arah garis ekuipotensial dapat mengurangi kemungkinan terjadinya pelepasan permukaan dalam situasi yang tidak mudah untuk menempatkan antarmuka pada besar sudut dengan garis medan listrik (Pearson et al., 1995).

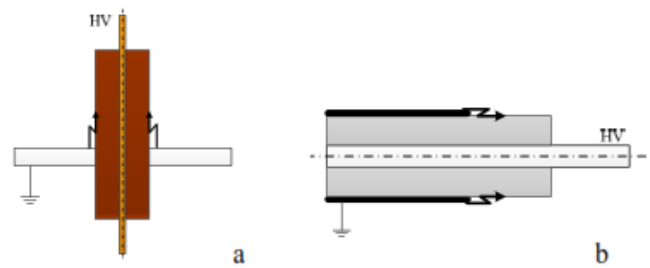

Gambar 1. Kondisi terjadinya Surface Discharge pada peralatan tegangan tinggi.

\section{II.1 Model Elektroda pengujian Surface Discharge}

Gambar 2 menunjukkan skema dari objek dan alat uji yang digunakan. Objek pengujian adalah PCB substrat epoxy (FR-4). Dengan Ukuran PCB persegi $(80 \mathrm{~mm} \times 80 \mathrm{~mm} \times 1,6 \mathrm{~mm}$ tebal) yang masih dilapisi tembaga foil dengan ukuran diameter $65 \mathrm{~mm}$, bahan epoxy memiliki nilai permisivitas 4.3-5.0. Model Elektroda menggunakan Medan homogen Model elektroda pelat-pelat dengan bentuk silinder dengan radius $50 \mathrm{~mm}$ dan ketebalan $5 \mathrm{~mm}$ untuk elektroda tegangan tinggi dan elektroda ground. Jarak antar elektroda tegangan tinggi dan elektroda ground pada objek uji adalah $0 \mathrm{~mm}$. Model rancangan pengujian ini untuk melakukan percobaan PD pada surface discharge pada PCB berisolasi udara dan minyak.

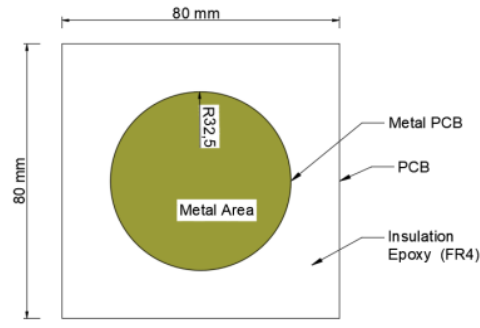

(a)

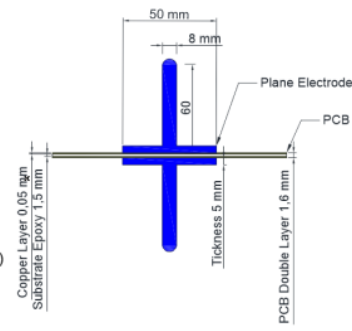

(b)
Gambar 2. (a) Model Elektroda dan (b) Desain PCB pengujian 
Intensitas medan magnet seragam secara teroritis dihasilkan dalam ruang terbatas antara dua elektroda bidang paralel dengan dimensi tak terbatas yang dipisahkan oleh jarak d dan mengalami perbedaan potensial V (Arora \& Mosch, 2011).

Nilai dari intensitas medan magnet seragam dapat dihitung dengan menggunakan persamaan berikut :

$$
E=\frac{V}{d} V / m
$$

Em = Magnitudo dari kuat medan listrik yang muncul $(\mathrm{V} / \mathrm{m})$

$\mathrm{V}=$ Tegangan yang diberikan pada elektroda pelat (V)

$\mathrm{d}=$ Jarak (gap) antara kedua elektroda (m)

\section{II.2 Rangkaian Percobaan PD}

Gambar 3 dan 4 memperlihatkan sistem pengukuran Partial Discharge berisolasi udara dan minyak. Dimana terdapat Jenis trafo uji yang digunakan adalah trafo step-up dengan kapasitas tegangan maksimal $100 \mathrm{kV}$, penggunaan Resistor pembatas untuk membatasi arus yang mengalir pada rangkain dengan nilai resistansi $6100 \Omega$, Coupling capacitor untuk melewatkan arus frekuensi tinggi dari sinyal Partial Discharge sehingga digunakan nilai kapasitansi $100 \mathrm{pF}$, masukan sumber tegangan tinggi AC dengan frekwensi $60 \mathrm{~Hz}$ yang dihubungkan pada elektroda pelat-pelat. Oscilloscope digunakan sebagai alat pengukuran besaran tegangan terhadap perubahan waktu dari sinyal yang dideteksi sensor RC Detektor dan HFCT.

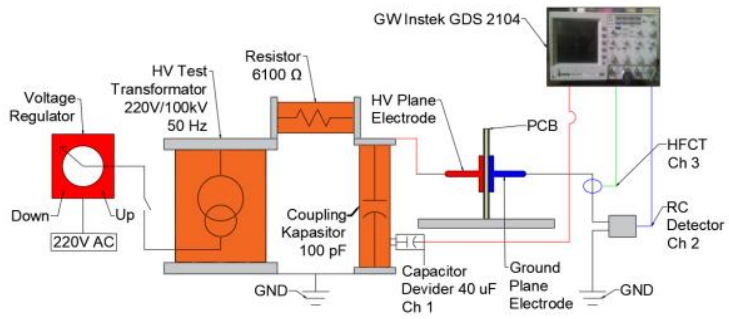

Gambar 3. Sistem pengukuran PD dengan Standar IEC 60270 berisolasi Udara

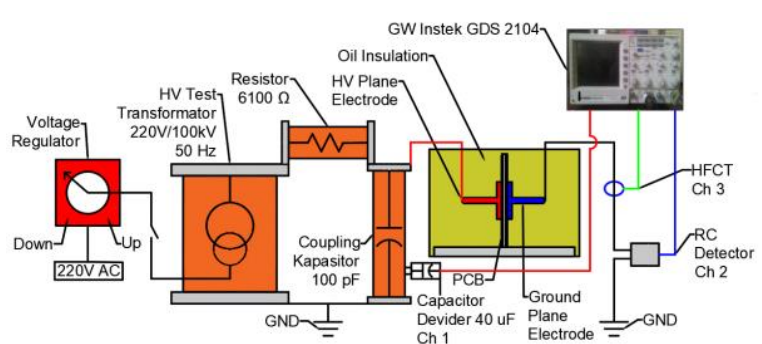

Gambar 4. Sistem pengukuran PD dengan Standar IEC 60270 berisolasi Air

\section{II.3 Prosedur Percobaan}

Pengukuran dilakukan pada 4 variasi tegangan yaitu 4.5, 5, 6 dan $7 \mathrm{kV}$ berisolasi udara dan 17, 18, 19 dan $20 \mathrm{kV}$ berisolasi minyak. Pendeteksian sinyal PD dengan menggunakan sensor RC Detektor dan HFCT dengan sampel data yang diambil sebanyak 40 kali percobaan dengan perolehan data berbentuk format .csv kemudian dilakukan pengolahan dengan menggunakan software Microsoft Excel dan OriginPro 2018.

Parameter yang digunakan dalam penelitian adalah : 1. PDIV (Partial Discharge Inception Voltage). 2. PDEV 3. Bentuk Gelombang Partial Discharge. 4. Pola Phasa Partial Discharge.

\section{Analisis dan Perancangan}

\section{III.1 PDIV}

PDIV pada udara dan minyak memiliki dua macam yaitu PDIV negatif dan positif, kedua jenis tersebut untuk PDIV negatif terjadi pada siklus negatif dan PDIV positif terjadi pada siklus positif. Tabel 1 memperlihatkan karakteristik sumber tegangan dan tegangan peak-peak pada isolasi udara dan minyak.

Tabel 1. PDIV Berisolasi Udara

\begin{tabular}{|c|c|c|c|c|c|c|c|c|}
\hline \multirow{3}{*}{$\begin{array}{c}\text { Sens } \\
\text { or }\end{array}$} & \multicolumn{4}{|c|}{ Isolasi Udara } & \multicolumn{4}{|c|}{ Isolasi Minyak } \\
\hline & \multicolumn{2}{|c|}{ PDIV Negatif } & \multicolumn{2}{|c|}{ PDIV Postif } & \multicolumn{2}{|c|}{ PDIV Negatif } & \multicolumn{2}{|c|}{ PDIV Postif } \\
\hline & $\begin{array}{c}\text { Tegan } \\
\text { gan } \\
(\mathrm{kV})\end{array}$ & $\begin{array}{l}\text { Vp-p } \\
(\mathrm{mV})\end{array}$ & $\begin{array}{c}\text { Tegan } \\
\text { gan } \\
(\mathrm{kV})\end{array}$ & $\begin{array}{l}\text { Vp-p } \\
(\mathrm{mV})\end{array}$ & $\begin{array}{c}\text { Tegan } \\
\text { gan } \\
(\mathrm{kV})\end{array}$ & $\begin{array}{l}\text { Vp-p } \\
(\mathrm{mV})\end{array}$ & $\begin{array}{c}\text { Tegan } \\
\text { gan } \\
(\mathrm{kV})\end{array}$ & $\begin{array}{l}\text { Vp-p } \\
(m V)\end{array}$ \\
\hline $\mathrm{RC}$ & 2,52 & $\begin{array}{l}54, \\
42\end{array}$ & 2,95 & $\begin{array}{c}141 \\
60\end{array}$ & 11,65 & $\begin{array}{c}33, \\
30\end{array}$ & 15,53 & $\begin{array}{l}29 \\
, 2\end{array}$ \\
\hline HFCT & 2,85 & $\begin{array}{c}45 \\
78\end{array}$ & 2,95 & $\begin{array}{c}41,7 \\
1\end{array}$ & 11,65 & $\begin{array}{c}25 \\
60\end{array}$ & 15,56 & 30 \\
\hline
\end{tabular}

Berdasarkan pada tabel 1 memperlihat perbedaan antara nilai sumber tegangan PDIV negatif dan positif 
antara isolasi udara dan isolasi minyak. Hal tersebut dipengaruhi oleh nilai dari permisivitas masingmasing media isolasi. Pada isolasi udara nilai dari PDIV negatif berada pada $2,52 \mathrm{kV}$ hal tersebut merupakan kemunculan pertamakali PD kemudian disusul dengan PDIV positif yang berapa pada nilai tegangan 2,95 kV. Nilai tengan PDIV positif menunjukkan lebih besar dari pada PDIV negatif. Hal ini disebabkan oleh polarisasi dielektrik dan depolarisasi dari sampel uji PCB epoxy.

PDIV pada isolasi minyak memperlihatkan bahwa PDIV negatif berada pada tegangan 11,65 kV dan PDIV positif $15,53 \mathrm{kV}$. Pada isolasi minyak juga memperlihatkan PDIV positif lebih besar daripada PDIV negatif.

Karakteristik PDIV pada surface discharge dengan menggunakan sensor RC dan HFCT memperlihatkan bahwa pada setiap sensor memiliki nilai tegangan yang berbeda-beda. Hal tersebut dikarenakan pada setiap sensor memiliki fungsi pengukuran yang berbeda. Dimana RC detektor digunakan untuk mengukur PD pada rangkian impedansi, HFCT untuk pengujian ini, sensor dimodelkan sebagai suatu sistem di mana inputnya adalah arus pulsa PD yang mengalir melaluinya dan outputnya adalah tegangan induksi yang diukur pada impedansi input dari alat ukur,

\section{III.2 PDEV}

Nilai PDEV dilakukan untuk menentukan nilai terendah dari kehilangan PD pada rangkaian pengujian. Nilai tegangan ini dipergunakan untuk menjadi acuan dari batas terendah kehadiran dari munculnya nilai PDIV pada objek pengujian dan pada media isolasi udara dan minyak yang digunakan.

Tabel 2. PDEV Berisolasi Udara

\begin{tabular}{cccc}
\hline \hline Sensor & Vmin $(\mathbf{k V})$ & Vmax $(\mathbf{k V})$ & PDEV $(\mathbf{k V})$ \\
\hline \hline RC & 2,07 & 2,35 & 2,19 \\
HFCT & 2,91 & 2,97 & 2,95 \\
\hline \hline
\end{tabular}

Tabel 2 memperlihatkan nilai tegangan kepunahan dari sensor yang digunakan, Baik untuk sensor RC Detektor dan HFCT. Hasil rata-rata memperlihatkan bahwa nilai tegangan $(\mathrm{kV})$ PDEV terendah dimiliki oleh sensor RC Detektor, kemudian HFCT. Nilai tegangan menunjukkan bahwa keberadaan PD pada objek dan media pengujian hilang pada nilai tegangan yang ditampilkan pada tabel diatas

\begin{tabular}{cccc}
\hline \hline Sensor & Vmin $(\mathbf{k V})$ & Vmax $(\mathbf{k V})$ & PDEV $(\mathbf{k V})$ \\
\hline \hline RC & 11,952 & 14,951 & 13,32 \\
HFCT & 14,24 & 14,824 & 14,496 \\
\hline \hline
\end{tabular}

Tabel 3 memperlihatkan nilai PDEV di media minyak hasil ini menunjukkan PDEV pada isolasi minyak lebih tinggi dari PDEV pada media isolasi udara. Nilai PDEV pada sensor RC dan HFCT memperlihatkan dimana sensor RC memiliki nilai PDEV terendah, hal ini mengindikasikan disaat sensor HFCT telah kehilangan PD namun pada RC detektor masih menunjukkan adanya PD pada tegangan yang terbaca oleh HFCT.

\section{III.3 Bentuk Gelombang}

1. Bentuk gelombang PD pada isolasi padat-gas (udara)
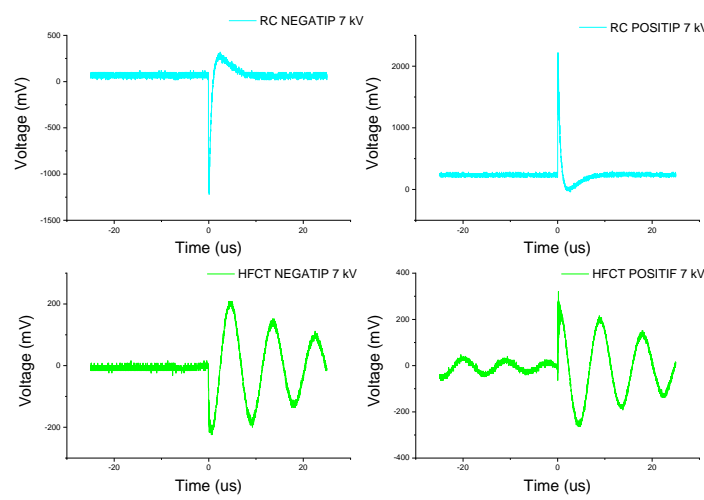

Gambar 5. Bentuk Gelombang RC dan HFCT pada isolasi padat- gas (udara)

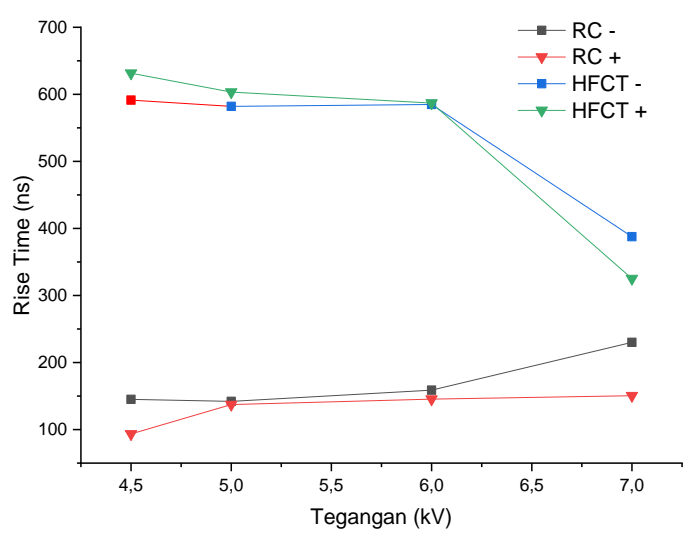

Gambar 6. Rise time udara

Tabel 3. PDEV Berisolasi Minyak 


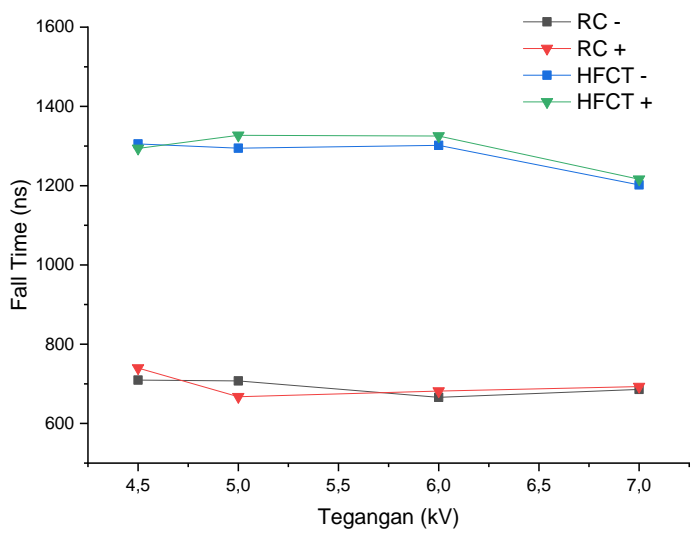

Gambar 7. Fall time udara

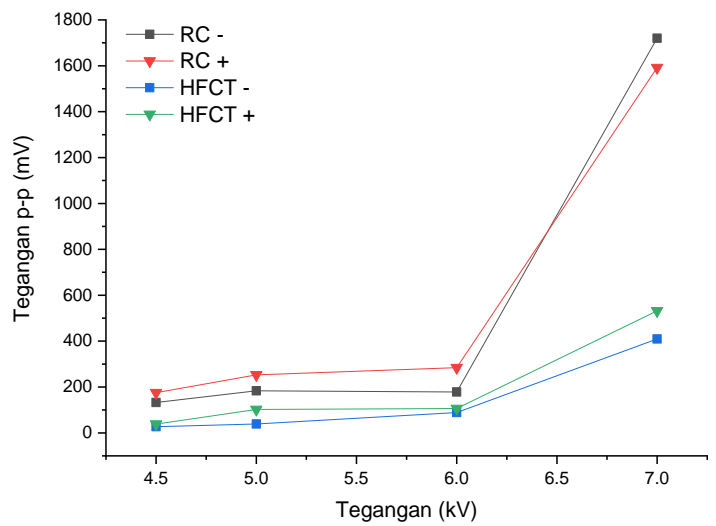

Gambar 8. Tegangan peak-peak udara

Bentuk Gelombang menunjukkan bahwa nilai Rise Time dari RC dan HFCT memiliki waktu yang lebih kecil dari pada nilai Fall Time. Hal tersebut dipengaruhi oleh proses ionisasi, dengan model elektroda antarmuka yang menyebabkan medan listrik diantara elektroda menimbulkan mobilitas elektron, elektron mula yang dihasilkan oleh ionisasi ekternal pada permukaan elektroda, kemudian elektron mula mengionisasi molekul-molekul gas sehingga menghasilkan elektron avalans dimana adanya kumpulan elektron dan ion positif. Dalam pergerakannya menuju anode, elektron avalans akan menumbuk molekul gas dan menghasilkan ion-ion positif dan elektron bebas baru. Elektron bebas baru ini akan membentuk banjiran elektron primer yang bergerak menuju anode sebagai arus listrik (Mansour et al., 2009).
2. Bentuk Gelombang PD pada isolasi padatminyak
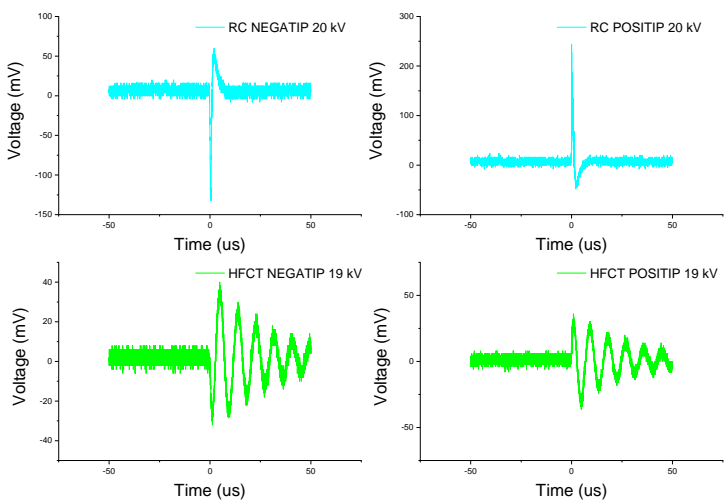

Gambar 9. Bentuk Gelombang RC dan HFCT pada isolasi padat- minyak

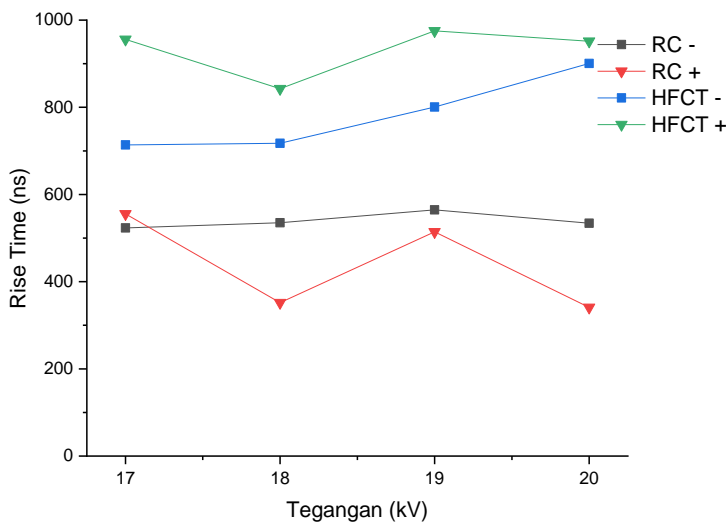

Gambar 10. Rise time minyak

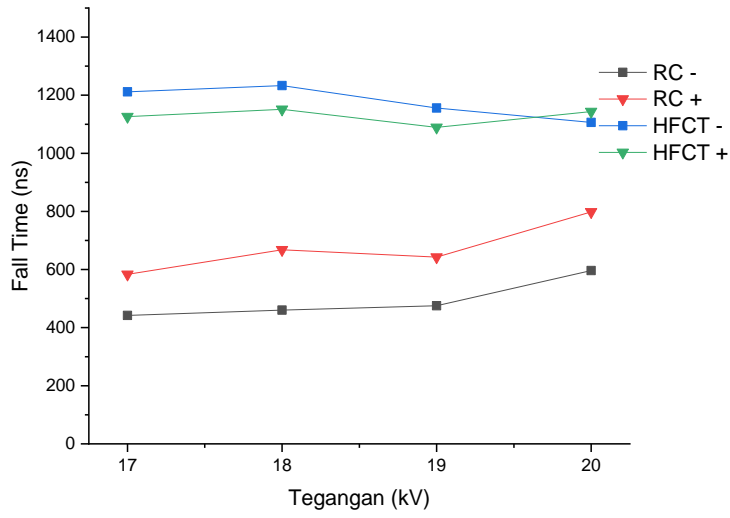

Gambar 11. Fall time minyak 


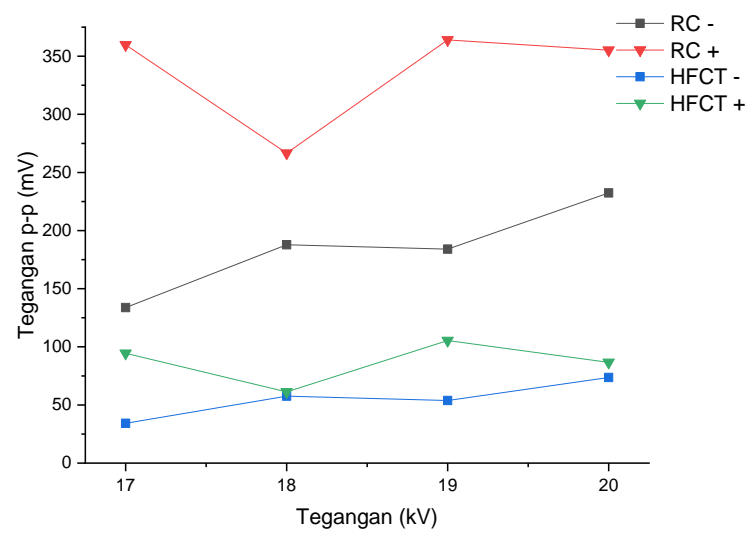

Gambar 12. Tegangan peak-peak minyak

Pada gambar 10, 11 dan 12 menunjukkan tipikal pelepasan pada permukaan, dari nilai variasi tegangan yang diberikan memperlihatkan lebar waktu kenaikan bentuk gelombang yang cenderung berubah dan terus meningkat dengan seiring bertambahnya waktu penuaan pada isolasi PCB. Hal ini menunjukkan bahwa nilai tegangan terapan berpengaruh terhadap lebar pulsa bentuk gelombang. Dari sinyal PD yang diperoleh karena proses pelepasan muatan di permukaan mengkonfirmasi bahwa pengujian pada peluahan dipermukaan memancarkan sinyal PD (Sarathi \& Sheema, 2013).

\section{III.4 Pola Phasa PD}

1. Surface Partial Discharge pada isolasi padat-gas (udara)

Pada gambar ini memperlihatkan pola $\varphi-q-n$ karakteristik Surface PD berisolasi udara dengan elektroda pelat-pelat disekitar tepi lingkaran PCB pada penerapan tegangan $4,5 \mathrm{kV}$ dan $7 \mathrm{kV}$.

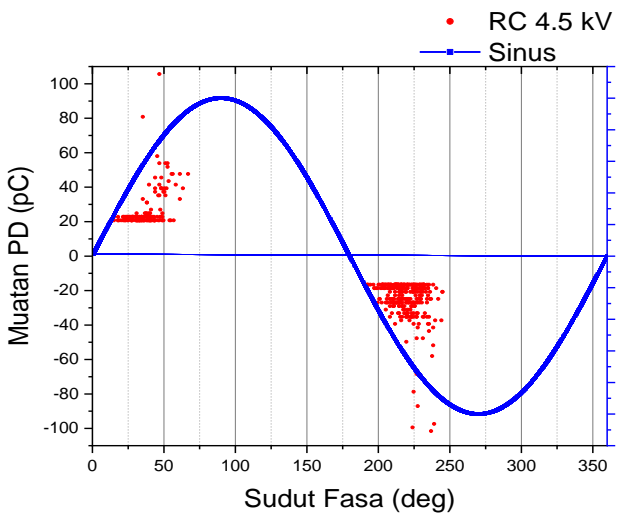

(a)

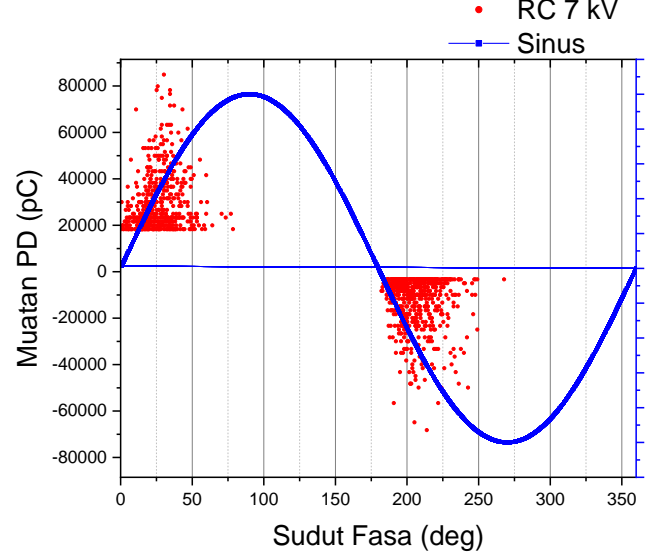

(b)

Gambar 13. Karakteristik Pola fasa $\varphi$-q-n (a) $4,5 \mathrm{kV}$ (b) $7 \mathrm{kV}$ berisolasi udara

Dari hasil pengamatan diketahui bahwa keberadaan sudut fasa PD $(\varphi)$ dengan penerapan tegangan 4,5 hingga $7 \mathrm{kV}$ posisi sudut fasa Surface PD negatif berada pada $206^{\circ}$ fasa hingga $220^{\circ}$ fasa. Sedangakan pada Surface PD positif berada pada $26^{\circ}$ hingga $40^{\circ}$ fasa. Kondisi ini tidak adanya indikasi terjadinya pergerseran fasa baik pada PD negatif dan PD positif.

Besar muatan PD (q) pada nilai PD negatif -26 $\mathrm{pC}$ hingga $-7450 \mathrm{pC}$ dan $\mathrm{PD}$ positif $29 \mathrm{pC}$ hingga 18830 pC pada penerapan tegangan 4,5 hingga $7 \mathrm{kV}$. Terjadinya PD dalam isolasi padat pada media udara dan minyak sangat tergantung pada turunan waktu dari tegangan yang diberikan sedangkan besarnya PD tergantung pada tegangan yang diberikan sesaat (Khayam \& Alhanif, 2016).

Jumlah PD (n) pada pengujian surface PD isolasi padat-udara diketahui dengan hasil perhitungan jumlah sinyal PD di siklus negatif dan positif pada tegangan 4,5 hingga $7 \mathrm{kV}$. Jumlah PD negatif sebanyak 318 hingga 818 dan PD positif sebanyak 155 hingga 759. Hasil tersebut memperlihatkan bahwa PD negatif lebih banyak dari jumlah PD positif, banyaknya jumlah sinyal PD tergantung pada nilai tegangan yang diterapkan. Bentuk pola Phasa memperlihatkan kecenderungan kenaikan besaran muatan positif dan negatif selaras dengan meningkatnya jumlah pelepasan muatan negatif dan positif.

2. Surface Partial Discharge pada isolasi padatminyak 


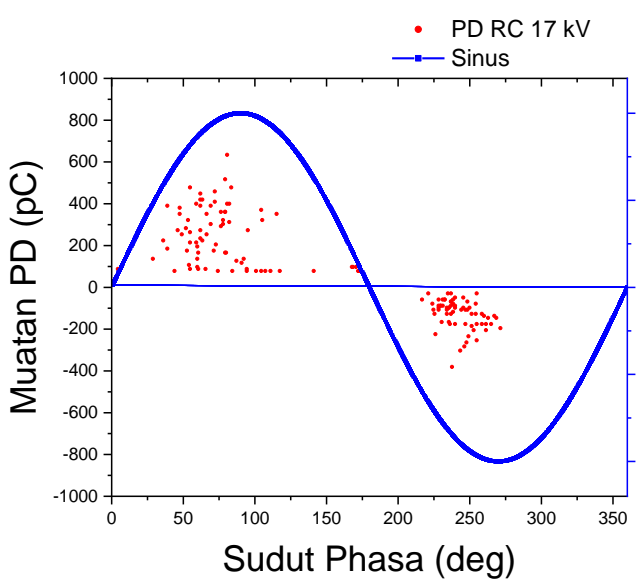

(a)

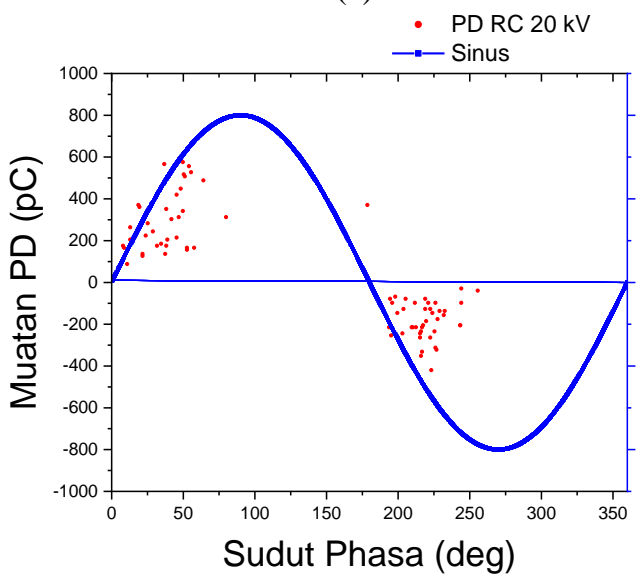

(b)

Gambar 14. Karakteristik Pola fasa $\varphi$-q-n (a) 4,5 kV (b) $7 \mathrm{kV}$ berisolasi minyak

Berdasarkan hasil pengukuran pola PD pada RC detektor pada isolasi minyak, posisi untuk sudut Phasa $(\varphi)$ PD positif berada pada setengah siklus positif terletak pada $10-120^{\circ}$ dan sudut Phasa PD negatif berada pada setengah siklus negatif dan terletak diantara 200-225. Hal ini menandakan bahwa muatan (q) PD berada pada posisi tersebut. Pada isolasi padat-minyak memperlihatkan jumlah PD positif lebih banyak dari jumlah PD negatif, dengan jumlah PD cenderung menurun baik pada PD negatif maupun positif

\section{III.5 Diskusi dan Analisis}

Untuk penerapan sumber tegangan dan besaran $\mathrm{PD}$, tren linear pada bentuk gelombang menunjukkan bahwa ada kecenderungan menuju saturasi dengan meningkatnya laju perubahan tegangan. Hal tersebut terjadi karena elektron awal umumnya muncul dengan penundaan stokastik, yang mana tidak terpengaruh oleh laju perubahan tegangan. Karena magnitudo PD bergantung pada tegangan saat PD terbentuk, hal tersebut menjelaskan mengapa sumber teggangan mengakibatkan magnitudo PD cenderung mencapai nilai tertinggi. Fenomena terjadinya PD pada tegangan yang lebih tinggi cenderung memiliki sisa medan listrik yang tertinggal (Wang, Li, \& Liu, 2017). Akibatnya, penurunan tegangan umumnya lebih tinggi dari yang seharusnya, dan muatan PD juga memiliki cenderung meningkat .

Pada pola Phasa PD pada isolasi udara keberadaan sudut pola Phasa PD negatif pada setiap kenaikan tegangan berubah-ubah, namun keberadaannya terletak pada sudut Phasa $180-270^{\circ}$ dalam siklus negatif dan sudut pola Phasa PD positif juga berubah-ubah, namun keberadaanya terletak pada sudut Phasa $0-90^{\circ}$ pada siklus positif. Sedangkan pada Isolasi minyak, posisi untuk sudut Phasa $(\varphi)$ PD positif berada pada setengah siklus positif terletak pada $10-120^{\circ}$ dan sudut Phasa PD negatif berada pada setengah siklus negatif dan terletak diantara $200-225^{\circ}$.

Terjadinya PD dalam isolasi padat pada media udara dan minyak sangat tergantung pada turunan waktu dari tegangan yang diberikan sedangkan besarnya PD tergantung pada tegangan yang diberikan sesaat (Khayam \& Alhanif, 2016). PD negatif, muatan negatif bergerak menuju permukaan isolator dan beberapa muatan ini mencapai permukaan dan kemudian diakumulasikan setelah kejadian PD. PD positif, muatan positif bergerak ke permukaan isolator dan kemudian, muatan ini menetralkan beberapa muatan negatif yang terakumulasi sebelumnya. Oleh karena itu, dianggap bahwa jumlah pulsa PD negatif dan positif adalah salah satu parameter utama yang dapat berhubungan dengan proses akumulasi muatan (Ardiansyah \& Khayam, 2019a).

Karakteristik pelepasan muatan PD pada isolasi udara pada permukaan PCB dimana aktivitas pelepasan kontinu pada permulaan dan distribusi Phasa yang terdefinisi dengan baik kemungkinan besar disebabkan oleh adanya elektron awal setiap kali tegangan awal tercapai (Ardiansyah \& Khayam, 2019b; Suwarno, 2014). Sedangkan pada isolasi minyak, setelah periode tertentu pada pengujian surface discharge, terdapat perubahan pola Phasa PD dimana jumlah muatan berkurang seperti yang 
ditunjukkan pada gambar 14. Kondisi tersebut karena terjadinya proses surface atau creeping discharge pada antarmuka PCB yang terendam oleh minyak dimana gangguan tersebut dapat terjadi dikondisi kerja normal. Surface discharge mengakibatkan adanya proses perambatan water treeing yang terjadi karena adanya tegangan terapan pada elektroda yang terhubung pada antarmuka PCB yang terhubung ke grounding (Gulski, 1995).

\section{KESIMPULAN DAN SARAN}

Terjadinya surface discharge pada isolasi padatgas (udara) dan isolasi padat-minyak dipengaruhi penerapan tegangan tinggi dan lamanya waktu penerapan yang terjadi yang memungkinan terjadinya pemulaan elekron avalanche, dan elektron bebas. Namun pada isolasi minyak terjadinya surface discharge sangat sulit terjadi karena nilai permisivitas naik hingga 2 kali lipat yang menyebabkan pada isolasi minyak nilai dari PD berada pada tegangan yang lebih tinggi dari pada isolasi udara.

Dari dua sensor yang digunakan dalam pengujian bahan uji PCB epoxy dengan pengukuran langsung, induktif dan elektromagnetik. Untuk pengukuran langsung dengan RC detektor memperlihatkan dimana memiliki tekanan rendah dari arus pulsa karena penerapan tegangan. Dengan rise time dan fall time lebih singkat. Sedangkan pada HFCT memiliki nilai rise time dan fall time lebih panjang dengan magnitudo lebih rendah dari RC.

Karakteristik pada bahan isolasi padat-gas (udara) dan padat-minyak memperlihatkan bahwa nilai permisivitas bahan isolasi berpengaruh terhadap nilai tegangan dari tahanan isolasi, posisi sudut fasa, besar muatan, dan jumlah muatan partial discharge

\section{REFERENSI}

60270, I. (2001). High-voltage test techniques Partial discharge measurements. The Journal of Engineering.

https://doi.org/10.1049/joe.2018.0172

Ardiansyah, N. P., \& Khayam, U. (2019a). Characteristics of Surface Discharge around the edges of a circle the PCB on model Plane-plane electrodes in Oil insulation. In 2019 2nd International Conference on High Voltage
Engineering and Power Systems (ICHVEPS) (pp. 1-6). Denpasar: IEEE. https://doi.org/10.1109/ICHVEPS47643.2019.9 011146

Ardiansyah, N. P., \& Khayam, U. (2019b). Discharge Characteristics of Acrylic Surface Around the Needle Tip of Needle-Plane Electrodes. 2018 Electrical Power, Electronics, Communications, Controls and Informatics Seminar, EECCIS 2018, (50), 79-84. https://doi.org/10.1109/EECCIS.2018.8692812

Arora, R., \& Mosch, W. (2011). High voltage and electrical insulation engineering (IEEE Press). New Jersey: John Wiley \& Sons, Inc.

Fu, P., Zhao, Z., Li, X., Cui, X., Wen, T., \& Mo, S. (2018). Surface discharge characteristics and initiation mechanism of PEEK in nitrogen under semi-square voltage. American Institute of Physics, 075322. https://doi.org/10.1063/1.5034060

Ghaffarian, M. (2015). Partial Discharge Signatures of Defects in Insulation Systems Consisting of Oil and Oil-impregnated Paper. https://doi.org/10.13140/RG.2.1.2775.4967

Gulski, E. (1995). Digital analysis of partial discharges. IEEE Transactions on Dielectrics and Electrical Insulation, 2(5).

Khayam, U., \& Alhanif, I. (2016). Design of RC circuit as partial discharge detector. Proceedings - Joint International Conference on Electric Vehicular Technology and Industrial, Mechanical, Electrical and Chemical Engineering, ICEVT 2015 and IMECE 2015, 323-328. https://doi.org/10.1109/ICEVTIMECE.2015.74 96708

Mansour, D. E. A., Kojima, H., Hayakawa, N., Endo, F., \& Okubo, H. (2009). Surface charge accumulation and partial discharge activity for small gaps of electrode/epoxy interface in sf6 gas. IEEE Transactions on Dielectrics and Electrical Insulation, 16(4), 1150-1157. https://doi.org/10.1109/TDEI.2009.5211869

Pearson, J. S., Farish, O., Hampton, B. F., Judd, M. D., Templeton, D., Pryor, B. M., \& Welch, I. M. (1995). Partial Discharge Diagnostics for Gas Insulated Substations. IEEE Transactions on 
Dielectrics and Electrical Insulation, 2(5), 893905.

Sarathi, R., \& Sheema, I. P. M. (2013). Understanding Surface Discharge Activity in Copper Sulphide Diffused Oil Impregnated Pressboard under AC Voltages. IEEE Transactions on Dielectrics and Electrical Insulation, 21, 674-682. https://doi.org/10.1109/TDEI.2013.004039

Suwarno. (2014). Phase resolved measurement and simulation of partial discharges in solid and liquid insulating materials. Proceedings of the International Symposium on Electrical Insulating Materials, 46-49. https://doi.org/10.1109/ISEIM.2014.6870716

Wang, J., Li, Q., \& Liu, S. (2017). Characteristics of Partial Discharge in Oil-paper Insulation System under High Frequency Voltage. IEEE International Conference on Dielectric Liquids $(I C D L)$. 